\title{
AGGRESSIVENESS AND PHYSIOLOGICAL SPECIALIZATION OF Septoria tritici Rob. ISOLATES
}

\author{
Jorge Omar Giecoํㅜ Jorge Dubcovsky²; Luis Eduardo Aranha Camargo ${ }^{3 *}$ \\ ${ }^{1}$ USP/ESALQ - Programa de Pós-Graduação em Genética e Melhoramento de plantas, C.P. 83 - 13400-970 - \\ Piracicaba, SP - Brasil. \\ ${ }_{3}^{2}$ Department of Agronomy \& Range Science, University of California, Davis, CA 95616 - USA. \\ ${ }^{3}$ USP/ESALQ - Depto. de Entomologia, Fitopatologia e Zoologia Agrícola, C.P. 9 - 13418-900 - Piracicaba, SP - \\ Brasil. \\ *Corresponding author <leacamar@esalq.usp.br>
}

\begin{abstract}
Pathogenicity tests verifying the behavior of Septoria tritici isolates should be considered as a priority in the selection of resistant wheat materials to this pathogen, since the aggressiveness of each isolate can vary significantly, causing problems in the evaluation and selection of resistant genotypes. The objective of this work was to determine whether physiologic specialization exists among Argentinean and American Septoria tritici isolates, through the analysis of their pathogenicity on cultivars and lines of bread wheat (Triticum aestivum L.). The experiments were carried out in Castelar-Argentina and in Davis-USA. In Castelar, a split plot design $(n=4)$ was used. The cultivars or lines were randomized in the plots and the isolates in the subplots. Each subplot consisted of three plants belonging to a cultivar or line. In Davis, a strip split plot design $(\mathrm{n}=6)$ was used. A pot containing three plants of each cultivar or line constituted the experimental plots. In both sites, the inoculation was made at the flag leaf phenological stage through foliar aspersion of a conidial suspension adjusted to $10^{6}-10^{8}$ conidia $\mathrm{mL}^{-1}$. Evaluations were made by recording the leaf area covered with pycnidia (LACP) at the flag leaf stage with the use of rating scales. Differences $(P \leq 0.0001)$ in LACP were detected among cultivars or lines. Isolate effects and the interaction cultivar $\times$ isolate were significant $(P \leq 0.0001)$. Variations in aggressiveness and virulence were found among the isolates, indicating the presence of horizontal and vertical resistance in the host cultivars. Key words: Mycosphaerella graminicola, Triticum aestivum, leaf blotch, vertical resistance, horizontal resistance
\end{abstract}

\section{AGRESSIVIDADE E ESPECIALIZAÇÃO FISIOLÓGICAEM ISOLADOS DE Septoria tritici Rob.}

RESUMO: Testes de patogenicidade destinados a verificar o comportamento de isolados de Septoria tritici frente a genótipos de trigo (Triticum aestivum L.) devem ser considerados como uma prioridade na seleção de materiais resistentes, já que a agressividade de cada isolado pode variar significativamente em função do hospedeiro. O objetivo do presente trabalho foi determinar se existe variação da agressividade ou especialização fisiológica em isolados de Septoria tritici Rob. originários de Argentina e EUA em cultivares e linhagens de trigo. Os experimentos foram estabelecidos em Castelar-Argentina e em Davis-EUA. Na primeira localidade utilizou-se um delineamento experimental em parcelas divididas com quatro repetições, onde as cultivares foram aleatorizadas nas parcelas e os isolados nas subparcelas. Cada subparcela foi composta por três plantas pertencentes a um determinado cultivar. Na segunda localidade, foi adotado um delineamento em blocos casualizados e arranjo em faixas, com seis repetições, onde as parcelas experimentais foram constituídas por um vaso contendo três plantas de cada cultivar. A inoculação foi feita no estádio fenológico de folha bandeira em ambas localidades com uma suspensão de conídios ajustada a uma concentração de $10^{6}-10^{8}$ esporos $\mathrm{mL}^{-1}$, empregando a técnica de inoculação por aspersão foliar. As avaliações foram feitas registrando-se a área foliar coberta por picnídios (AFCP) no estádio de folha bandeira com auxílio de escalas de notas. Em ambas localidades foram detectadas diferenças significativas ( $P \leq 0,0001)$ em AFCP entre cultivares. Foram também detectados efeitos significativos de isolados e da interação cultivares $\mathrm{x}$ isolados $(P \leq 0,0001)$. Foram detectadas variações na agressividade e virulência dos isolados sugerindo a presença de resistência horizontal e vertical no material vegetal testado. Testes de patogenicidade destinados a verificar o comportamento de isolados de Septoria tritici devem ser considerados como uma prioridade na seleção de materiais de trigo resistentes a este patógeno.

Palavras-chave: Mycosphaerella graminicola, Triticum aestivum, mancha foliar, resistência vertical, resistência horizontal 


\section{INTRODUCTION}

Plants present two basic types of resistance to pathogens: vertical and horizontal resistance. Both types of resistance are defined in terms of two variables: the host and the pathogen. In this system, host resistance to a disease can exist only under two alternative forms. The variation observed in the host determines the presence of horizontal resistance. The differential interaction between both the pathogen and the host determines the existence of vertical resistance. Aggressiveness and virulence are terms utilized to describe the pathogen's behavior in the presence of horizontal and vertical resistance, respectively. Both types can coexist, i.e., resistance in a host could be the result of a combination between vertical and horizontal resistance (Vanderplank, 1984).

Vertical resistance is also known in plant breeding as "specific", and is determined by one or a few genes that impart complete resistance to a certain pathogen. This type of resistance is also known as "short-term" resistance, and also known as qualitative, monogenic, or strain-specific resistance (Gair et al., 1987).

Horizontal resistance, in turn, is usually associated with several genes and imparts an incomplete type of resistance; the host is attacked by the pathogen in a higher or lower degree, depending on the number and type of genes involved in the resistance. This type of resistance is also known as general resistance, field resistance, non-specific, quantitative, or polygenic resistance (Jacobs \& Broers, 1989; McIntosh, 1998; Robert et al., 2000).

Both types of resistance have been found in wheat. Narvaez \& Caldwell (1954), Rillo \& Caldwell (1966), Wilson (1979), Lee \& Gough (1984), Rosielle \& Brown (1979), Potts \& Hughes (1987), and Somasco et al. (1996), analyzing different wheat cultivars, found qualitative resistance, where one to three major genes would be responsible for the resistance in the studied cultivars. On the other hand, Eyal (1981), Jlibene et al. (1994), and Simon \& Cordo (1998), reported the presence of polygenic or quantitative resistance with the predominance of additive genetic effects.

The presence of the perfect form of the fungus Mycosphaerella graminicola (Fuckel) Schroeter has been reported in many parts of the world, such as New Zealand (Sanderson, 1972), Australia (Brown et al., 1978), Chile (Madariaga, 1986), England (Scott et al., 1988), Brazil (Mehta, 1989), the Netherlands (Shaw \& Royle, 1989), the USA - California and Oregon (Madariaga et al., 1989; Ahmed et al., 1995), Germany (Vereet et al., 1990), and France (Halama, 1996). The presence of the sexual form of the pathogen provides an additional mechanism by which its genetic variability can be increased (Ahmed et al., 1995). Evidences of differential interactions between Septoria tritici isolates and wheat cultivars were described in Israel, Morocco and the USA, suggesting the physi- ological specialization of the pathogen (Eyal et al., 1973; King et al., 1983; Saadaoui, 1987).

The objective of this work was to determine whether variations exist in the aggressiveness or physiological specialization of Septoria tritici Rob. isolates from Argentina and the USA, by means of inoculations on wheat cultivars and lines.

\section{MATERIALAND METHODS}

\section{Isolates}

\section{Experiment 1: Castelar-Argentina}

Thirty Septoria tritici isolates were tested to analyze their pathogenicity on 11 wheat cultivars. The isolates were obtained from locations within wheat-producing regions in the Province of Buenos Aires (Table 1).

\section{Experiment 2: Davis-USA}

The isolates included in this experiment were USA 00005 and CA 30. The first was isolated from line UC 1036 in Colusa, CA. The second isolate (CA 30) was ob-

Table 1 - Cultivars and collection locations of the isolates utilized in pathogenicity tests in Castelar, Argentina.

\begin{tabular}{|c|c|c|c|}
\hline \multicolumn{4}{|c|}{ Septoria tritici isolates } \\
\hline Isolate & Cultivar source & Geographical source* & Year \\
\hline $1: \mathrm{I} 7$ & Buck ñanque & Balcarce & 1998 \\
\hline $2: \mathrm{I} 6$ & Buck ñanque & Balcarce & 1998 \\
\hline $3: I 122$ & Klein cacique & Barrow & 1998 \\
\hline $4: I 76 \mathrm{G}$ & Prointa Federal & Balcarce & 1998 \\
\hline $5: I 77 G$ & ProintaFederal & Balcarce & 1998 \\
\hline $6: I 27$ & Buck arrayán & Balcarce & 1998 \\
\hline $7: I 42 E$ & Prointa oas is & Balcarce & 1998 \\
\hline 8:I89 & Klein cacique & Barrow & 1998 \\
\hline $9: I 31$ & Prointa oasis & Balcarce & 1998 \\
\hline $10: I 78 G$ & Prointa federal & Balcarce & 1998 \\
\hline $11: \mathrm{I} 16$ & Buck ñanque & Balcarce & 1998 \\
\hline 12:IA1 & Klein cacique & LosHornos & 1999 \\
\hline $13: I 109$ & Klein cacique & Barrow & 1998 \\
\hline $14: I 7 \tilde{n} v$ & Buck ñanque & Balcarce & 1998 \\
\hline $15:$ IR7 & Klein cacique & Los Hornos & 1999 \\
\hline $16: I R 2$ & Klein cacique & Los Hornos & 1999 \\
\hline $17: 174$ & Prointa federal & Balcarce & 1998 \\
\hline $18: \mathrm{I} 88$ & Klein cacique & Alberti & 1998 \\
\hline 19:I44 & Buck ñanque & Balcarce & 1998 \\
\hline $20: I 1.4$ & Klein cacique & Los Hornos & 1999 \\
\hline 21:I108 & Klein cacique & Barrow & 1998 \\
\hline 22:I2P & Prointa is la verde & Pergamino & 1998 \\
\hline $23: \mathrm{I} 13$ & Buck ñanque & Balcarce & 1998 \\
\hline $24: I 26$ & Buck arrayán & Balcarce & 1998 \\
\hline $25: I 12$ & Buck ñanque & Balcarce & 1998 \\
\hline $26: I A 3$ & $\mathrm{~K}$ lein cacique & Los Hornos & 1999 \\
\hline 27:I30 & Buck arrayán & Balcarce & 1998 \\
\hline $28: I 65 G$ & Prointa federal & Balcarce & 1998 \\
\hline 29:I100 & Klein cacique & Balcarce & 1998 \\
\hline $30: I 14$ & Buck ñanque & Balcarce & 1998 \\
\hline
\end{tabular}

*Province of Buenos Aires, Argentina. 
tained from wheat cultivars in the experimental area of the Department of Agronomy and Range Science, Davis, CA. Isolate USA 00005 was chosen since it has high aggressiveness and infects Tadinia (80\% of the leaf area necrotic and covered with pycnidia), in addition to other resistant cultivars such as Veranopolis, Frontana, IAS 20, and Bulgaria 88 (Goodwin, personal communication). The objective of this experiment was to verify the aggressiveness of isolate USA 00005 in relation to isolate CA 30, to which Tadinia, Veranopolis, Frontana, IAS 20, and Bulgaria 88 are resistant, and to determine whether this isolate can be considered as a physiological variant of Septoria tritici.

\section{Plant material}

\section{Experiment 1: Castelar-Argentina}

The 11 different cultivars utilized in this study were selected because of their reaction to Septoria tritici in previous assays; three of them are resistant, four are susceptible, three are moderately resistant and one is moderately susceptible (Somasco et al., 1996; Simon \& Cordo, 1998). The characterization of these cultivars, including their source and reaction to Septoria tritici, are presented in Table 2.

\section{Experiment 2: Davis-USA}

In this study, 20 different cultivars and 10 CIMMYT lines resistant to Septoria tritici were utilized. The cultivars were selected because of their reaction to Septoria tritici in previous assays; the group consisted of resistant, moderately resistant, moderately susceptible, and susceptible cultivars and/or lines (Somasco et al., 1996; Simon \& Cordo, 1998) (Table 3).

Table 2 - Main characteristics of cultivars utilized in pathogenicity tests in Castelar, Argentina.

\begin{tabular}{lcc}
\hline Cultivar & Source & Reaction to Septoria tritici \\
\hline Tadinia & UCD & $\mathrm{R}$ \\
Yecora rojo & UCD & $\mathrm{S}$ \\
UC 554 & UCD & MR \\
INIA 66R & INIA & MR-MS \\
UC 1041 & UCD & R \\
Cooperación Maipun & Queaca & $\mathrm{R}$ \\
Cooperación Calquin & Queaca & $\mathrm{S}$ \\
Marcos Juarez INTA & INTA & $\mathrm{S}$ \\
HLP* & INTA & $\mathrm{MR}$ \\
Leones INTA & INTA & $\mathrm{S}$ \\
Baguette 12 & Nidera & MS \\
\hline
\end{tabular}

R: resistant; S: susceptible; MR: Moderately resistant; MS: Moderately susceptible. UCD: University of California-Davis, USA. Queaca: Química Estrella-Asociación de Cooperativas Argentinas, Argentina. INTA: Instituto Nacional de Tecnología Agropecuaria, Argentina. Nidera: Private company, Argentina. INIA: Instituto Nacional de Investigación Agropecuaria, Chile.
Table 3 - Main characteristics of cultivars utilized in the pathogenicity tests in Davis, CA, USA.

\begin{tabular}{|c|c|c|}
\hline Cultivar/Line & Source & $\begin{array}{c}\text { Reaction to } \\
\text { Septoria tritici }\end{array}$ \\
\hline CIMMYT 1 & CYMMYT & $\mathrm{R}$ \\
\hline CIMMYT 2 & CYMMYT & $\mathrm{R}$ \\
\hline CIMMYT 3 & CYMMYT & $\mathrm{R}$ \\
\hline CIMMYT 4 & CYMMYT & $\mathrm{R}$ \\
\hline CIMMYT 5 & CYMMYT & $\mathrm{R}$ \\
\hline CIMMYT 6 & CYMMYT & $\mathrm{R}$ \\
\hline CIMMYT 7 & CYMMYT & $\mathrm{R}$ \\
\hline CIMMYT 8 & CYMMYT & $\mathrm{R}$ \\
\hline CIMMYT 9 & CYMMYT & $\mathrm{R}$ \\
\hline CIMMYT 10 & CYMMYT & $\mathrm{R}$ \\
\hline Israel 493 & UCD & $\mathrm{R}$ \\
\hline Bulgaria 88 & $\mathrm{UCD}$ & $\mathrm{R}$ \\
\hline Veranopolis & UCD & $\mathrm{R}$ \\
\hline Tadinia & UCD & $\mathrm{R}$ \\
\hline WR 33 TA 5056 & UCD & $\mathrm{R}$ \\
\hline Chinese Spring S. 7D & UCD & $\mathrm{R}$ \\
\hline IAS 20 & UCD & $\mathrm{R}$ \\
\hline Marcos Juarez INTA & INTA & $\mathrm{S}$ \\
\hline Leones INTA & INTA & S \\
\hline Don Ernesto INTA & INTA & $\mathrm{R}$ \\
\hline Prointa Isla verde & INTA & S \\
\hline Klein Toledo & INTA & $\mathrm{R}$ \\
\hline Klein Atlas & INTA & $\mathrm{S}$ \\
\hline Coop. Maipun & Queaca & $\mathrm{R}$ \\
\hline Coop. Calquin & Queaca & $\mathrm{S}$ \\
\hline Synthetic 43 & UCD & $\mathrm{R}$ \\
\hline Opata 85 & $\mathrm{UCD}$ & $\mathrm{S}$ \\
\hline UC 554 & UCD & MR \\
\hline INIA 66R & UCD & MR-MS \\
\hline Yecora rojo & UCD & $\mathrm{S}$ \\
\hline
\end{tabular}

R: resistant; S: susceptible; MR: Moderately resistant; MS: Moderately susceptible. CIMMYT: Centro Internacional de Mejoramiento de Maíz y Trigo- México; UCD: University of California-Davis, USA; Queaca: Química Estrella-Asociación de Cooperativas Argentinas, Argentina; INTA: Instituto Nacional de Tecnología Agropecuaria, Argentina.

\section{Evaluation of resistance}

\section{Experiment 1: Castelar-Argentina}

An experimental design in split plots $(n=4)$ was adopted, in which cultivars were randomized in the plots and isolates were randomized in the subplots. Each subplot consisted of three plants belonging to a given cultivar. Cultivars were sown in May, 2000. The inoculation was made 70 days after plant emergence (DAE), corresponding to the flag leaf phenological stage. The subplots of each cultivar were inoculated with a spore suspension of the corresponding Septoria tritici isolate, using the leaf sprinkling inoculation technique (Dhingra \& Sinclair, 1986; Eyal et al., 1987). The inoculum concentration was $10^{6}$ $10^{8}$ spores $\mathrm{mL}^{-1}$. After inoculation, a humid chamber (36 h) was prepared by covering the blocks with plastic film. 
Thirty days after inoculation, plants were evaluated and the leaf area covered with pycnidia (LACP) was recorded, according to Eyal \& Brown's scale (1976).

\section{Experiment 2: Davis-USA.}

A strip split plot experimental design $(n=6)$ was utilized, where the isolates were randomly allocated to each strip. Each plot consisted of a pot containing three plants belonging to a given cultivar. Cultivars were sown in December, 2000. The experiment was conducted in controlled environment. The inoculation was made at 70 DAE (flag leaf phenological stage). The inoculation technique and the evaluation of severity of the disease followed the scheme detailed for Experiment 1.

\section{Statistical analysis}

Analyses of variance and mean comparison tests (Tukey) were conducted for the LACP character (proc GLM). The SAS version 8.0 statistical software (SAS, 1999) was used to analyze the data.

\section{RESULTS AND DISCUSSION}

\section{Experiment 1: Castelar-Argentina}

Differences $(P \leq 0.0001)$ were detected among cultivars and isolates. The cultivar $\times$ isolate interaction was also significant $(P \leq 0.0001)$. Cultivars Yecora rojo, Leones INTA, Cooperación Calquin and Marcos Juarez INTA, behaved as susceptible; Tadinia, Cooperación Maipun, UC 1041, and HLP behaved as resistant, while Baguette 12, UC 554, and INIA 66R showed intermediate behavior to all isolates tested (Table 4).

The isolates showed differences in their aggressiveness for the 11 cultivars. Isolates I89, I42E, I14, IR2, I6, I109, I122, and I31 were the most aggressive. Iso-

Table 4 - Tukey test for leaf area covered with pycnidia (LACP) involving the eleven cultivars.

\begin{tabular}{ll}
\hline Cultivar & LACP \\
\hline Yecora rojo & $3.29 \mathrm{a}$ \\
Leones INTA & $3.12 \mathrm{ab}$ \\
Cooperación Calquin & $3.05 \mathrm{~b}$ \\
Marcos Juarez INTA & $2.97 \mathrm{~b}$ \\
Baguette 12 & $2.73 \mathrm{c}$ \\
INIA 66R & $1.74 \mathrm{~d}$ \\
UC 554 & $1.54 \mathrm{e}$ \\
HLP & $1.35 \mathrm{ef}$ \\
UC 1041 & $1.27 \mathrm{fg}$ \\
Cooperación Maipun & $1.10 \mathrm{gh}$ \\
Tadinia & $1.06 \mathrm{~h}$ \\
\hline
\end{tabular}

LACP: Eyal \& Brown Scale: $(0-5)(0=0 \%, 1=12 \%, 2=25 \%, 3=$ $50 \%, 4=75 \%, 5=87 \%$ ).

Means followed by a common letter are not different by Tukey test $(\alpha=0.01)$. lates I109, I122, I31, I26, I76G, I77G, I30, I44, I2P, I100, I108, I13, IA3, I7, I16, I88, and I7ñv exhibited intermediate aggressiveness. Finally, isolates I74, IR7, I65G, I27, I1.4, I12, I78G, and IA1 were the least aggressive (Table 5).

The genotypes of the isolates interacted differentially with the genotypes of the host cultivars, indicating the presence of vertical resistance (Figure 1). The differential interaction can be observed between isolates I27 and I31, and cultivars 3 and 4; I27 and I6 and cultivars 4 and 5; I6 and I31 and cultivars 5 and 6, and finally between isolates I89 and I42 and cultivars 6 and 7 .

This differential interaction can be interpreted from two standpoints. From the pathogen's standpoint (isolate), its physiological specialization, by means of the pathogenicity process selection, determined the existence of host-specific virulence genes. The presence of the perfect form of the fungus in many parts of the world is a

Table 5 - Tukey test for leaf area covered with pycnidia (LACP), involving thirty $S$. tritici isolates inoculated on eleven cultivars.

\begin{tabular}{ll}
\hline Is olate & LACP \\
\hline I89 & $4.43 \mathrm{a}$ \\
I42E & $4.39 \mathrm{a}$ \\
I14 & $2.81 \mathrm{~b}$ \\
IR2 & $2.42 \mathrm{c}$ \\
I6 & $2.41 \mathrm{c}$ \\
I109 & $2.38 \mathrm{c}$ \\
I122 & $2.38 \mathrm{c}$ \\
I31 & $2.32 \mathrm{c}$ \\
I26 & $2.22 \mathrm{~cd}$ \\
I76G & $2.21 \mathrm{cde}$ \\
I77G & $2.08 \mathrm{def}$ \\
I30 & $2.01 \mathrm{defg}$ \\
I44 & $1.98 \mathrm{efgh}$ \\
I2P & $1.97 \mathrm{fgh}$ \\
I100 & $1.97 \mathrm{fgh}$ \\
I108 & $1.89 \mathrm{fghi}$ \\
I13 & $1.80 \mathrm{ghij}$ \\
IA3 & $1.78 \mathrm{ghij}$ \\
I7 & $1.78 \mathrm{ghij}$ \\
I16 & $1.75 \mathrm{hijk}$ \\
I88 & $1.73 \mathrm{ijkl}$ \\
I7ñv & $1.73 \mathrm{jjkl}$ \\
IA1 & $1.71 \mathrm{jjklm}$ \\
I78G & $1.71 \mathrm{jjklm}$ \\
I12 & $1.67 \mathrm{jjklm}$ \\
I1.4 & $1.67 \mathrm{ijklm}$ \\
I27 & $1.63 \mathrm{jklm}$ \\
\hline I65G & $1.53 \mathrm{klm}$ \\
I74 & $1.51 \mathrm{~lm}$ \\
\hline IACP & $1.48 \mathrm{~m}$ \\
\hline
\end{tabular}

LACP: Eyal \& Brown Scale: $(0-5)(0=0 \%, 1=12 \%, 2=25 \%, 3=$ $50 \%, 4=75 \%, 5=87 \%$ ).

Means followed by a common letter do not differ by Tukey test ( $\alpha$ $=0.01$ ). 


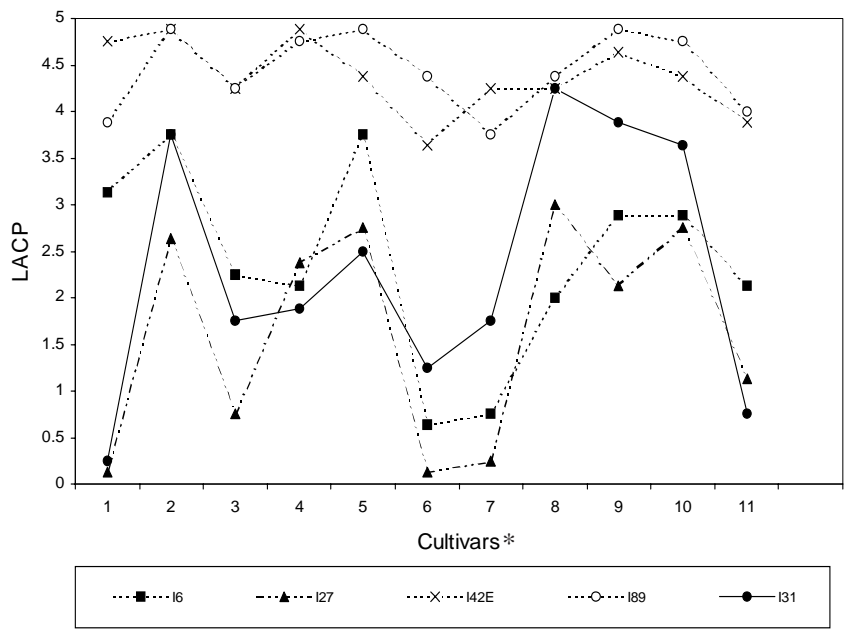

*: 1: Tadinia, 2: Yecora rojo, 3: UC 554, 4: Inia 66R, 5: UC 1041, 6: Cooperación Maipun,

7: Cooperación Calquin, 8:Marcos Juárez INTA, 9:HLP, 10: Leones INTA and 11: Baguette 12.

Figure 1 - Leaf area covered with pycnidia (LACP) resulting from the interaction between five Septoria tritici isolates and eleven wheat cultivars.

determinant factor in its evolutionary process, through the generation of variants adapted to certain host cultivars.

From the host's standpoint (cultivar), the interaction with certain isolates in a given geographical area allowed the manifestation of resistance genes specific for those isolates, which were perpetuated through the process of artificial selection aimed at the formation of new cultivars. In agreement with these results, evidences of differential interactions between Septoria tritici isolates and wheat cultivars have been found in Israel, Morocco, United States and England, suggesting that the physiological specialization of the pathogen has occurred (Eyal et al., 1973; King et al., 1983; Saadaoui, 1987; Ahmed et al., 1995; Kema et al., 1996a, 1996b; Brown et al., 2001).

The horizontal resistance can be explained based on the aggressiveness manifested by isolates I 42E and I89. These two isolates are characterized by being highly aggressive, attacking the resistant cultivars and inducing greater severity of the disease in the susceptible cultivars. This can be seen in Table 6, where a comparison is presented between the LACP for isolates I42E and I89 and the mean LACP for the remaining 28 isolates.

\section{Experiment 2: Davis-USA}

Differences $(P \leq 0.0001)$ were detected in the analysis of variance for LACP between isolates and between cultivars. The isolate $\times$ cultivar interaction was also significant $(P \leq 0.0001)$.

Cultivars Opata 85, Inia 66R, Yecora rojo, Cooperación Calquin, Prointa Isla Green, and Klein Atlas behaved as susceptible; CYMMYT 2, WR 33 TA 5056, Synthetic 43, Israel 493, UC 554, Klein Toledo, CIMMYT 3, Don Ernesto INTA, Chinese Spring S. 7D, CIMMYT
Table 6 - Comparison between the severity of LACP obtained for isolates I42E and I89 and the mean severity obtained for the remaining 28 isolates.

\begin{tabular}{lccc}
\hline & Isolate I42E & Isolate I89 & 28 isolates \\
\hline Cultivar & LACP & LACP & LACP \\
\hline 1: Tadinia & 4.75 & 3.88 & 0.83 \\
2: Yecora rojo & 4.88 & 4.88 & 3.17 \\
3: UC 554 & 4.25 & 4.25 & 1.34 \\
4: INIA 66R & 4.88 & 4.75 & 1.52 \\
5: Coop. Calquin & 4.38 & 4.88 & 2.94 \\
6: Coop. Maipun & 3.63 & 4.38 & 0.90 \\
7: HLP & 4.25 & 3.75 & 1.17 \\
8: Marcos Juarez INTA & 4.25 & 4.38 & 2.87 \\
9: Leones INTA & 4.63 & 4.88 & 3.00 \\
10: Baguette 12 & 4.36 & 4.75 & 2.60 \\
11: UC 1041 & 3.86 & 4.00 & 1.08 \\
\hline
\end{tabular}

LACP: Eyal \& Brown Scale: $(0-5)(0=0 \%, 1=12 \%, 2=25 \%, 3=$ $50 \%, 4=75 \%, 5=87 \%)$.

6, Cooperación Maipun, and CIMMYT 10 behaved as resistant; CIMMYT 7, CIMMYT 5, Bulgaria 88, CIMMYT 4, Leones INTA, CIMMYT 9, CIMMYT 8, Veranopolis, Tadinia, CIMMYT 1, Marcos Juarez INTA, and IAS 20 manifested an intermediate behavior in relation to isolates USA 00005 and CA 30 (Table 7).

The USA 00005 and CA 30 isolates showed differences $(P \leq 0.0001)$ in relation to the mean LACP when inoculated on the thirty wheat cultivars (USA 00005 LACP $=2.04$ and CA $30 \mathrm{LACP}=1.23$ ). Isolate USA 00005 was, on average, more aggressive than isolate CA30.

Isolate USA 00005 caused greater severity of the disease in most cultivars evaluated (Figure 2). This type of interaction works under the assumption that the horizontal type of resistance occurs in the cultivars analized. However, the presence of cultivars exhibiting an opposite behavior, i.e., showing greater susceptibility to isolate CA 30 (cultivars 18, 19, and 30), allowed to observe the presence of a differential interaction between isolates and host cultivars, a fact that provides evidence of the presence of vertical resistance in the population of cultivars under analysis.

In addition, in the inoculation with isolate USA 00005 it was possible to observe that a group of cultivars resistant to isolate CA 30 - Tadinia, Bulgaria 88, Veranopolis, and IAS 20 - behaved as susceptible to this isolate, manifesting high severity of the disease, as evidenced by the LACP values (Figure 2). The occurrence of differential interactions between genotypes from hosts and from isolates suggest the presence of a gene-to-gene interaction. The USA 00005 isolate can be considered as a variant of Septoria tritici that carries virulence genes that determine the ability to infect cultivars resistant to the CA 30 Septoria tritici isolate (Figure 2). The USA 
00005 isolate proved to be virulent on cultivars that carry the Stb1 (Bulgaria 88), Stb2 (Veranopolis), and Stb4 (Tadinia) resistance genes.

Kema et al. (1996b) and Kema \& Van Silfhout (1997), also found differential interactions between wheat genotypes and Septoria tritici isolates. Gene-to-gene interactions between wheat genotypes and Septoria tritici isolates, suggesting the presence of a strain-specific type of resistance, were reported by McCartney et al. (2002) and Brading et al. (2002).

Ahmed et al. (1995), studying Septoria tritici isolates from Oregon, California, and Texas, demonstrated the existence of a specific isolate-environment (location) adaptation. This specific adaptation and the high genetic variability that exists within populations of the pathogen (Mc Donald \& Martinez, 1990) would be the factors that determine the selection of host-specific and locally-adapted virulent strains.

Table 7 - Tukey test for Leaf area with lesions, involving the thirty cultivars inoculated with isolates USA 00005 and CA 30.

\begin{tabular}{ll}
\hline Cultivar & LACP \\
\hline Opata 85 & $4.39 \mathrm{a}$ \\
Inia 66R & $4.28 \mathrm{a}$ \\
Yecora rojo & $4.05 \mathrm{~b}$ \\
Coop. Calquin & $3.38 \mathrm{~b}$ \\
Prointa Isla verde & $2.77 \mathrm{c}$ \\
Klein Atlas & $2.40 \mathrm{~d}$ \\
CIMMYT 7 & $2.36 \mathrm{ef}$ \\
CIMMYT 5 & $2.31 \mathrm{ef}$ \\
Bulgaria 88 & $2.23 \mathrm{ef}$ \\
CIMMYT 4 & $2.10 \mathrm{efg}$ \\
Leones INTA & $2.06 \mathrm{fgh}$ \\
CIMMYT 9 & $1.91 \mathrm{ghi}$ \\
CIMMYT 8 & $1.88 \mathrm{ghi}$ \\
Veranopolis & $1.86 \mathrm{ghi}$ \\
Tadinia & $1.78 \mathrm{hij}$ \\
CIMMYT 1 & $1.72 \mathrm{ij}$ \\
Marcos Juarez INTA & $1.62 \mathrm{ij}$ \\
IAS 20 & $1.51 \mathrm{j}$ \\
CIMMYT 10 & $0.83 \mathrm{k}$ \\
Coop. Maipun & $0.78 \mathrm{k}$ \\
CIMMYT 6 & $0.65 \mathrm{k1}$ \\
Chinese Spring S. 7D & $0.37 \mathrm{~lm}$ \\
Don Ernesto INTA & $0.36 \mathrm{~lm}$ \\
CIMMYT 3 & $0.32 \mathrm{~lm}$ \\
Klein Toledo & $0.31 \mathrm{~m}$ \\
UC 554 & $0.31 \mathrm{~m}$ \\
Israel 493 & $0.12 \mathrm{~m}$ \\
Synthetic 43 & $0.12 \mathrm{~m}$ \\
WR 33 TA 5056 & $0.08 \mathrm{~m}$ \\
CIMMYT 2 & $0.08 \mathrm{~m}$ \\
\hline IAC: Eyal 2 Brown & \\
\hline
\end{tabular}

LACP: Eyal \& Brown Scale: $(0-5)(0=0 \%, 1=12 \%, 2=25 \%, 3=$ $50 \%, 4=75 \%, 5=87 \%$ ).

Means followed by a common letter do not differ by Tukey test $(\alpha=0.01)$

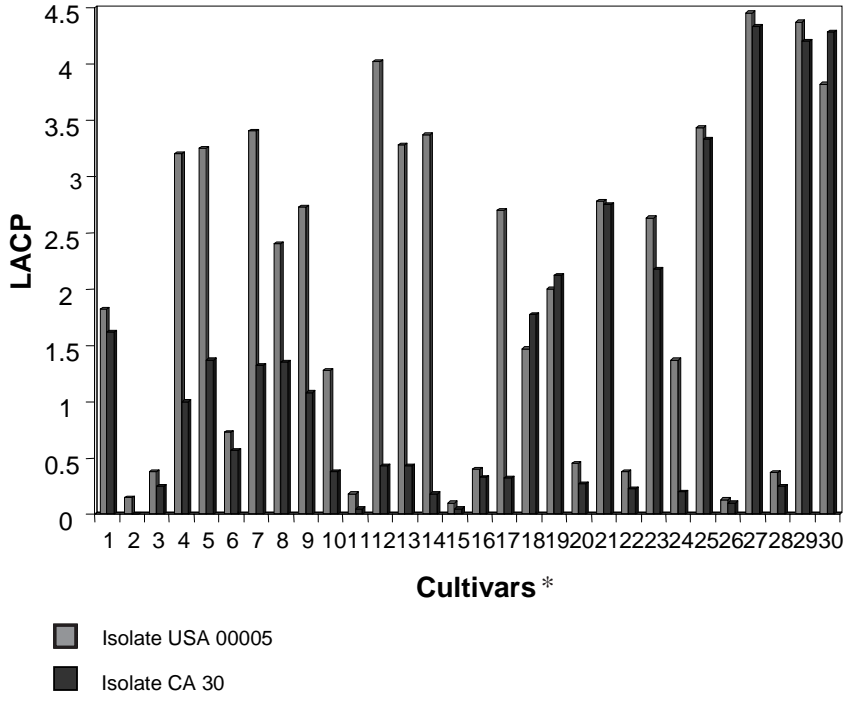

*1: CIMMYT 1, 2: CIMMYT 2, 3: CIMMYT 3, 4: CIMMYT 4, 5: CIMMYT 5, 6: CIMMYT 7: CIMMYT 7, 8: CIMMYT 8, 9: CIMMYT 9, 10: CIMMYT 10, 11: Israel 493, 12: Bulgaria 88, 13: Veranopolis, 14: Tadinia, 15: WR 33 TA 5056, 16: Chinese Spring S. 7D, 17: IAS 20, 18: Marcos Juarez INTA, 19: Leones INTA, 20: Don Ernesto INTA, 21: Prointa Isla Verde, 22: Klein Toledo, 23: Klein Atlas, 24: Cooperación Maipun, 25: Cooperación Calquin, 26: Synthetic 43, 27: Opata 85, 28: UC 554, 29: Inia 66R and 30: Yecora rojo.

Figure 2 - Leaf area covered with pycnidia (LACP) of thirty wheat cultivars inoculated with isolates USA 00005 and CA 30, respectively.

In the case of pathogens that have a high genetic variability such as Septoria tritici, the presence of new cultivars that carry different resistance gene arrays determines, in turn, the selection of new virulence factors in the pathogen. As a consequence, new strains of the pathogen will appear, bearing the ability to break the resistance of the new cultivar. These new strains quickly disseminate at the same pace in which the new cultivars are extensively planted, so that in a short period of time (two or three commercial planting seasons) they become susceptible. When this happens, the cultivars must be replaced with others carrying new resistance genes (Gair et al., 1987).

The complexity of the interactions found in the Septoria tritici-wheat pathosystem requires breeders to have a profound knowledge about them when a breeding program aimed at achieving resistance to the disease is to be established, whatever the approach that is taken. The pathogenicity tests designed to verify the behavior of Septoria tritici isolates must be considered as a priority in the selection of wheat materials resistant to this pathogen, since the aggressiveness of each isolate can vary significantly, causing problems in the evaluation and selection of resistant genotypes. The selection of a quantitative-type approach for a breeding program targeted at resistance to Septoria tritici would be more convenient because, in addition to allowing the difficulties imposed 
by the specific isolate-cultivar interactions to be overcome, it would also contribute to prevent the emergence of strains conditioned by the use of cultivars with vertical resistance.

\section{ACKNOWLEDGEMENTS}

This research received financial support from Fundação de Amparo a Pesquisa do Estado de São PauloBrazil. The research in the USA was funded by the USDA-IFAFS 2001-04462 competitive grant. The authors are especially thankful to Cristina Cordo (Facultad de Ciencias Agrícolas y Forestales de La Plata-Universidad Nacional de La Plata, Buenos Aires-Argentina), Stephen B. Goodwin (Department of Botany and Plant Pathology, Purdue University-Indiana-USA), and Barney Ward (Department of Phytopathology, University of CaliforniaDavis-USA), for the Septoria tritici isolates supplied for this research.

\section{REFERENCES}

AHMED, H.U.; MUNDT, C.C.; COAKLEY, S.M. Host-pathogen relationship of geographically diverse isolates of Septoria tritici and wheat cultivars. Plant Pathology, v.44, p.838-847, 1995.

BRADING, P.A.; VERSTAPPEN, E.C.P.; KEMA, G.H.J.; BROWN, J.K.M. A gene - for - gene relationship between wheat and Mycosphaerella graminicola, the Septoria tritici blotch pathogen. Phytopathology, v.92, p.439-445, 2002.

BROWN, J.S.; KELLOCK, A.W.; PADDICK, R.G. Distribution and dissemination of Mycosphaerella graminicola (Fuckel) Schroeter in relation to the epidemiology of speckled leaf blotch of wheat. Australian Journal of Agricultural Research, v.29, p.11391145, 1978.

BROWN, J. K.; KEMA, G. H. J.; FORRER, H. R.; VERSTAPPEN, E. C. P.; ARRAIANO, L. S.; BRADING, P. A.; FOSTER, E. M.; FRIED, P. M.; JENNY, E. Resistance of wheat cultivars and breeding lines to septoria tritici blotch caused by isolates of Mycosphaerella graminicola in field trials. Plant Pathology, v.50, p.325-338, 2001.

DHINGRA, O.D.; SINCLAIR, J.B. Basic plant pathology methods. 3.ed. Boca Raton: CRC Press, 1986. p.119-178: Establishment of disease and testing for resistance.

EYAL, Z. Integrated control of Septoria diseases of wheat. Plant Disease, v.65, p.763-768, 1981.

EYAL, Z.; BROWN, M.B. A quantitative method for estimating density of Septoria tritici pycnidia on wheat leaves. Phytopathology, v.66, p.11-14, 1976.

EYAL, Z.; AMIRI, Z.; WAHL, I. Physiologic specialization of Septoria tritici. Phytopathology, v.63, p.1087-1091, 1973.

EYAL, Z.; SCHAREN, A.L.; PRESCOTT, J.M.; van GINKEL, M. Enfermedades del trigo causadas por Septoria: Conceptos y métodos relacionados con el manejo de estas enfermedades. México, D.F.: CIMMYT, 1987. 45p.

GAIR, R.; JENKINS, J.E.E.; LESTER, E. Cereal pests and diseases. 4.ed. Suffolk: Farming Press, 1987. 268p.

HALAMA, P. The occurrence of Mycosphaerella graminicola teleomorph of Septoria tritici in France. Plant Pathology, v.45, p.135-138, 1996.

JACOBS, T.; BROERS, L.H.M. The inheritance of host plant effect on latency period of wheat leaf rust in spring wheat. Estimation of gene action and number of effective factors in $\mathrm{F}_{1}, \mathrm{~F}_{2}$ and backcross generations. Euphytica, v.44, p.197-206, 1989.

JLIBENE, M.; GUSTAFSON, J.P.; RAJARAM, S. Inheritance of resistance to Mycosphaerella graminicola in hexaploid wheat. Plant Breeding, v.112, p.301-310, 1994.
KEMA, G.H.J.; VAN SILFHOUT, C.H. Genetic variation for virulence and resistance in the wheat-Mycosphaerella graminicola pathosystem III. Comparative seedling and adult plant experiments. Phytopathology, v.87, p.266-272, 1997.

KEMA, G.H.J.; SAYOUD, R.; ANNONE, J.G.; van SILFHOUT, C.H. Genetic variation for virulence and resistance in the wheatMycosphaerella graminicola pathosystem I. Analysis of interactions between pathogen isolates and host cultivars. Phytopathology, v.86, p.200-212, 1996a.

KEMA, G.H.J.; SAYOUD, R.; ANNONE, J.G.; van SILFHOUT, C.H. Genetic variation for virulence and resistance in the wheatMycosphaerella graminicola pathosystem II. Analysis of interactions between pathogen isolates and host cultivars. Phytopathology, v.86, p.213-220, 1996b.

KING, J.E.; COOK, R.J.; MELVILLE, S.C. A review of Septoria diseases of wheat and barley. Annals of Applied Biology, v.103, p.345373, 1983.

LEE, T.S.; GOUGH, F.J. Inheritance of Septoria leaf blotch (S. tritici) and Pyrenophora tan spot (P. tritici repentis) resistance in Triticum aestivum cv. Carifen 12. Plant Disease, v.68, p.848-851, 1984.

MADARIAGA, R.B. Presença en Chile de Mycosphaerella graminicola (Fuckel) Schroeter, estado sexuado de Septoria tritici Rob. ex Desm. Agricultura Técnica, v.46, p.209-211, 1986.

MADARIAGA, R.B.; GILCHRIST, D.G.; MARTENSEN, A.N. Presence and role of Mycosphaerella graminicola in California wheat. Phytopathology, v.79, p.1141, 1989.

MCCARTNEY, C.A.; BRÛLÉ-BABEL, A.L.; LAMARI, L. Inheritance of race-specific resistance to Mycosphaerella graminicola in wheat. Phytopathology, v.92, p.138-144, 2002.

Mc DONALD, B.A.; MARTINEZ, J.P. DNA restriction fragment length polymorphisms among Mycosphaerella graminicola (anamorph Septoria tritici) isolates collected from a single wheat field. Phytopathology, v.80, p.1368-1373, 1990.

McINTOSH, R.A. Breeding wheat for resistance to biotic stresses. Euphytica, v.100, p.19-34, 1998.

METHA, Y.R. Occurrence of Septoria tritici and its perfect state in Brazil. In: INTERNATIONAL WORKSHOP ON SEPTORIA DISEASES OF CEREALS, 3. Zurich, 1989. Proceedings. Zurich: Swiss Federal Research Station for Agronomy, 1989. p.34-35.

NARVAEZ, I.; CALDWELL, R.M. Inheritance of resistance to leaf blotch of wheat caused by Septoria tritici. Phytopathology, v.47, p.529-530, 1954.

POTTS, D.A.; HUGHES, G.R. Inheritance of resistance to Septoria tritici in wheat. Canadian Journal of Plant Science, v.67, p.285, 1987. /Abstract/

RILLO, A.O.; CALDWELL, R.M. Inheritance of resistance to Septoria tritici in Triticum aestivum subsp. vulgare 'Bulgaria 88'. Phytopathology, v.56, p.897, 1966. /Abstract/

ROBERT, O.; DEDRYVER, F.; LECONTE, M.; ROLLAND, B.; DE VALLEVIEILLE-POPE, C. Combination of resistance tests and molecular tests to postulate the yellow rust resistance gene Yr17 in bread wheat lines. Plant Breeding, v.119, p.467-472, 2000.

ROSIELLE, A.A.; BROWN, A.G.P. Inheritance, heritability and breeding behavior of three sources of resistance to Septoria tritici in wheat. Euphytica, v.28, p.385-392, 1979.

SAADAOUI, E.M. Physiologic specialization of Septoria tritici in Morocco. Plant Disease, v.71, p.153-155, 1987.

SANDERSON, F.R.A Mycosphaerella species as the ascogenous state of Septoria tritici Rob. and Desm. New Zealand Journal of Botany, v.10, p.707-710, 1972.

SAS INSTITUTE. SAS/STAT User's Guide, Release 8.0 edition. Cary: SAS Institute, 1999.

SCOTT, P.R.; SANDERSON, F.R.; BENEDIKZ, P.W. Ocurrence of Mycosphaerella graminicola (Fuckel) Schroeter teleomorph of Septoria tritici on wheat in UK. Plant Pathology, v.37, p.285290, 1988.

SHAW, M.W.; ROYLE, D.J. Airborne inoculum as a source of Septoria tritici (Mycosphaerella graminicola) infections in the winter wheat crops in the UK. Plant Pathology, v.38, p.35-43, 1989. 
SIMON, M.R.; CORDO, C.A. Diallel analysis of four resistance components to Septoria tritici in six crosses of wheat (Triticum aestivum). Plant Breeding, v.117, p.123-126, 1998.

SOMASCO, O.A.; QUALSET, C.O.; GILCHRIST, D.G. Single-gene resistance to Septoria tritici blotch in the spring wheat cultivar 'Tadinia'. Plant Breeding, v.115, p.261-267, 1996.

VANDERPLANK, J.E. Disease resistance in plants. Orlando: Academic Press, 1984. 194p.

VEREET, J.A.; HOFFMANN, G.M.; PORTNER, J. Nachweis des Teleomorph Mycosphaerella graminicola (Fuckel) Schroeter (Anamorph: Septoria tritici Rob. apud Desm.) in der Bundesrepublik Deutschland. Journal of Phytopathology, v.130, p.105-110, 1990.
WILSON, R.E. Resistance to Septoria tritici in two wheat cultivars determined by independent, single dominant genes. Australian Plant Pathology, v.8, p.16-18, 1979.

Received July 25, 2002

Accepted April 28, 2004 